\title{
MAKNA KOMUNIKASI KELUARGA BAGI WANITA KARIER: STUDI FENOMENOLOGI MENGENAI MAKNA KOMUNIKASI KELUARGA BAGI WANITA KARIER DI KOTA BANDUNG
}

\author{
Ferane Aristrivani Sofian \\ Marketing Communication Department, Faculty of Economic and Communication, BINUS University \\ Jln. K.H. Syahdan No. 9, Palmerah, Jakarta Barat 11480 \\ ferane_as@binus.ac.id/ ieya.fey@gmail.com
}

\begin{abstract}
Currently, the role of women has shifted from traditional to modern roles. From just having a traditional role to bear children and take care of the household, women now have a social role which can be a career in various areas of life with higher education are supported. The role of a woman when they entered the stage of marriage seems to be so complex, when different interests collide. The method used in this study is qualitative, while the approach is phenomenology. In general, qualitative research is the process of research to understand the phenomenon, based on a tradition of research with the typical method, with the object of society's problems. There are five motives that make a career woman pursue her careeer, those are helping their husband to fulfill household living cost, apply knowledge, socialization, have their own income, and self-actualization. Having a career for career women is a gift from God and the struggle and sacrifice to support life in the form of work and creativity that benefit others. Having family for career women is a priceless gift from God in a river of happiness therefore becoming part of a family must be maintained carefully. Communicating for career women, is a real form of compassion, caring, and love to keep the marriage intact. Communicating between mother and child for career women is a real form of love and care in teaching and educating children to maintain familiarity with the child.
\end{abstract}

Keywords: career woman, meaning, family communication

\begin{abstract}
ABSTRAK
Peran wanita telah bergeser dari peran tradisional menjadi modern. Dari hanya memiliki peran tradisional untuk melahirkan anak dan mengurus rumah tangga, kini wanita mempunyai peran sosial dimana dapat berkarier dalam berbagai bidang kehidupan dengan didukung pendidikan yang tinggi. Peran wanita ketika memasuki jenjang perkawinan tampak menjadi begitu kompleks ketika berbagai kepentingan saling berbenturan. Metode yang digunakan dalam penelitian ini adalah kualitatif, sedangkan pendekatannya adalah fenomenologi. Secara umum penelitian kualitatif adalah proses penelitian untuk memahami fenomena, didasarkan pada tradisi penelitian dengan metode yang khas, dengan objek masalah masyarakat. Lima macam motif yang berasal dari dalam diri para wanita karier dalam meniti kariernya yaitu membantu perekonomian rumah tangga, mengaplikasikan ilmu, sosialisasi, memiliki penghasilan sendiri, dan aktualisasi diri. Memiliki karier bagi wanita karier, adalah anugerah dari Tuhan yang diraih dengan perjuangan dan pengorbanan serta sesuatu yang berharga yang menjadi penunjang bagi kehidupan serta bagian dari diri yang merupakan hasil karya dan kreatifitas yang bermanfaat bagi orang lain. Memiliki keluarga bagi wanita karier, adalah sumber kebahagiaan utama dalam kehidupan yang merupakan anugerah dan titipan dari Tuhan serta sesuatu yang berharga yang telah menjadi bagian dari diri yang harus terbina dan terjaga. Berkomunikasi antara wanita karier dengan suami adalah sebagai bentuk nyata dari rasa sayang, kepedulian, dan rasa cinta serta sebagai cara untuk menjaga kedekatan atau keakraban dengan suami dan keutuhan perkawinan. Berkomunikasi antara ibu dan anak bagi wanita karier, adalah sebagai bentuk nyata rasa sayang dan peduli, sebagai cara untuk mengajar dan mendidik anak serta sebagai cara untuk menjaga keakraban dengan anak.
\end{abstract}

Kata kunci: Wanita Karier, Makna, Komunikasi Keluarga 


\section{PENDAHULUAN}

Seiring berkembangnya zaman, peran wanita tidak hanya terbatas sebagai istri bagi suami dan ibu bagi anak-anak. Wanita yang dahulu hanya bergantung pada suami untuk memenuhi kebutuhannya tetapi saat ini sudah berubah, tidak sedikit wanita yang dapat memenuhi kebutuhannya bahkan ada yang penghasilannya melebihi suami. Saat ini berbagai seni kehidupan mulai terbuka lebar bagi wanita. Salah satunya adalah dengan menjadi wanita karier.

Karier adalah sebuah kata dari bahasa Belanda; carriere, yang berarti perkembangan dan kemajuan dalam pekerjaan seseorang. bisa juga berarti sebagai proses pekerjaan tertentu. Karier dalam istilah kamus besar bahasa Indonesia berarti perkembangan dan kemajuan baik pada kehidupan, pekerjaan atau jabatan seseorang. Biasanya pekerjaan yang dimaksud adalah pekerjaan yang mendapatkan imbalan berupa gaji maupun uang.

Banyak persoalan yang dialami oleh ibu rumah tangga yang bekerja di luar rumah, mulai dari bagaimana mengatur waktu dengan suami dan anak sampai mengurus tugas-tugas rumah tangga dengan baik. Ada yang bisa menikmati peran ganda tersebut, namun ada yang kesulitan sehingga menimbulkan persoalan-persoalan rumit yang kian berkembang dalam hidup sehari-hari. Jika dengan bekerja ternyata mendatangkan problem yang cukup memusingkan, maka pertanyaannya, apakah manfaat seorang ibu pergi bekerja mencari nafkah di luar rumah?

Fenomena wanita karier yang supersibuk dengan tekanan-tekanan pekerjaan (atasan dan kondisi/lingkungan pekerjaan), jarak dan waktu tempuh pekerjaan dan pergaulan metropolitan, menciptakan dilema bagi wanita pekerja untuk memutuskan apakah akan terus menjadi wanita karier atau berhenti bekerja. Terlebih lagi ketika situasi tersebut membuat hubungan keluarga semakin jauh dan tidak terurus. Jika dibiarkan maka akan berdampak pada retaknya hubungan suami istri, kenakalan anak dan remaja atau bahkan kehancuran keluarga.

Kesetaraan gender dan emansipasi di Indonesia memang semakin diperhatikan, ini terlihat dari banyaknya wanita yang terlibat dalam berbagai aktivitas, pekerjaan, dan jabatan. Tidak sedikit wanita Indonesia yang memiliki posisi penting dalam pemerintahan, perusahaan besar, atau dewan legislatif. Namun demikian tetap ada yang berbeda antara pria dan wanita. Kodrat wanita tidak dapat dipungkiri bahwa dia bertanggung jawab dalam kelangsungan keluarga yang utuh, kokoh, dan harmonis.

Maka menjadi sangat menarik membandingkan kasus nyata yang terjadi dengan seorang aktivis feminisme yang semula aktif berbicara tentang keharusan wanita untuk berkarier atau bekerja bernama asli Chaerani (Anni Iwasaki) yang kemudian setelah menikah justru menyerukan wanita untuk bekerja di rumah saja. Bahkan dianjurkan agar para wanita yang bekerja di luar rumah, segera kembali menata rumahnya. Ini dibuktikan dari data penelitian di Jepang yang menyebutkan sedikit wanita yang bekerja di luar rumah mempunyai anak-anak yang lebih berkualitas baik secara intelektual dan kepribadian. Sebaliknya kemorosotan kualitas anak-anak justru terjadi bagi keluarga dimana kaum ibunya mengagungkan karier dengan bekerja di luar rumah seperti di Amerika. (Istiyanto, 2004)

Hal ini adalah fenomena paling umum yang menjadi dilema bagi wanita. Selama ini banyak wanita terpecah konsentrasinya antara karier dan rumah tangga, sementara ia sangat ingin berkarier sepenuhnya. Tapi di sisi lain, wanita juga ingin menjadi ibu rumah tangga sejati. Walaupun banyak yang mengklaim bisa membagi waktu dengan baik antara karier dan rumah tangga, kesuksesan antara karier dan rumah tangga adalah dua hal yang sangat berbeda. Peran ganda antara wanita karier dan ibu rumah tangga sering menimbulkan konflik pada diri wanita karier, sehingga seringkali wanita harus memilih antara karier atau rumah tangga. 
Melalui sebuah observasi dan wawancara dengan banyak wanita karier sukses, Emma Charlotte Brown-seorang penulis Australia-menyimpulkan bahwa untuk keluar dari dilema antara keluarga atau karier bergantung bagaimana wanita memandang nilai sebuah kebahagiaan dalam hidupnya. Sebagian wanita menilai bahwa tiada kebahagiaan lain kecuali melihat anak-anak tumbuh didampingi seorang ibu yang dapat membimbing dan menemani sang anak sepanjang waktu. Itu artinya, seorang wanita akan benar-benar bahagia bila dapat memenuhi perannya sebagai ibu. "The real mother for their children," seorang ibu yang benar-benar hadir untuk anaknya. Namun, sebagian wanita lain berpendapat tak perlu harus meninggalkan dunia kerja sepanjang keluarga dan anak-anak dapat menerima hal tersebut. Pendapat ini menegaskan harus ada usaha untuk memenuhi keinginan agar dua unsur penting dalam hidup wanita yang telah berumah tangga itu berjalan harmonis (Wahyuni, 2008).

Fungsi dan peran utama sebagai orang tua mengalami pergeseran ketika para orang tua lebih mengejar karier dan materi. Ibu rumah tangga yang memilih menjadi wanita karier dengan bekerja di luar rumah, membuat perhatian terhadap keluarga menjadi berkurang. Waktu bersama keluarga hampir tidak ada, anak-anak dibesarkan dan dirawat oleh seorang pembantu atau baby sitter bahkan ada yang menitipkan anak mereka di tempat penitipan anak. Di kota-kota besar di Indonesia, termasuk di Kota Bandung, hal ini merupakan suatu kenyataan yang tidak dapat dipungkiri, sehingga usaha untuk mewujudkan keharmonisan dalam keluarga memerlukan suatu hubungan komunikasi yang baik antara anggota-anggota dalam keluarga tersebut.

Fenomena wanita sibuk yang menjadi eksekutif top di perusahaan, terjadi di semua kota besar di dunia, termasuk di Kota Bandung. Sosiolog Roby Muhamad menyebut, mereka berada di lingkar budaya elsewhere. Mereka ada di mana-mana sekaligus tidak berada di mana-mana. Ada kalanya mereka duduk dalam meeting, tetapi mengontrol kesibukan kantor lewat alat komunikasi. Di waktu lain mereka bersama keluarga, tapi juga sedang 'berada' di tengah klien, berkomunikasi 'sangat dekat' lewat ipad atau laptop. Sebegitu ketatnya waktu, sementara, mereka tak bisa lepas dari kenyataan bahwa mereka makhluk sosial. (Maharani, 2008).

Berdasarkan fenomena komunikasi yang terjadi tersebut, peneliti tertarik untuk mengkaji lebih dalam mengenai apa motif wanita dalam mengejar karier dan bagaimana pandangan mereka mengenai karier dan keluarga serta bagaimana mereka berkomunikasi dengan keluarga sehingga peneliti dapat mengetahui dan memahami alasan wanita memilih berkarier daripada menjadi ibu rumah tangga dan memahami bagaimana berkomunikasi dengan keluarga pada wanita karier. Peneliti berusaha mengetahui dan memahami makna kehidupan keluarga yang harmonis bagi wanita karier dalam pandangan wanita karier itu sendiri dan mengamati interaksi wanita karier dengan keluarganya serta mencari kekurangan dan kelebihan dari komunikasi tersebut sehingga peneliti dapat merumuskan kesimpulan dari pola komunikasi yang diperoleh dan memberikan saran untuk keadaan yang diinginkan oleh sebuah keluarga khususnya keluarga seorang wanita karier yaitu terciptanya hubungan yang harmonis antara suami dengan istri maupun orang tua dengan anak.

\section{Fokus Penelitian}

Berdasarkan penjelasan di atas, maka fokus dalam penelitian ini dapat dirumuskan sebagai berikut: Apa makna karier, keluarga dan komunikasi keluarga bagi wanita karier di Kota Bandung?

\section{Pertanyaan Penelitian}

Pertanyaan penelitian yang digunakan sebagai rambu-rambu dalam penelitian ini antara lain: (1) Apa motif yang melatarbelakangi seorang wanita untuk menjadi seorang wanita karier? (2) Apa pendapat wanita karier mengenai karier dan keluarga? (3) Apa pendapat wanita karier mengenai komunikasi keluarga? 


\section{METODE}

Penelitian ini menggunakan metode kualitatif. Menurut Jane Richie dalam Moleong (2001:6) penelitian kualitatif adalah upaya untuk menyajikan dunia sosial, dan perspektifnya di dalam dunia dari segi konsep, perilaku, persepsi dan persoalan tentang manusia yang diteliti.

Salah satu perspektif yang digunakan dalam penelitian kualitatif adalah perspektif fenomenologi. Penggunaan perspektif fenomenologi ini dimaksudkan untuk merekonstruksi kehidupan manusia ke dalam bentuk yang mereka alami sendiri.

Pendekatan fenomenologi termasuk dalam pendekatan subjektif atau interpretif (Mulyana, 2003:59), sebagai salah satu dari dua sudut pandang tentang perilaku manusia yaitu pendekatan objektif dan pendekatan subjektif. Pendekatan objektif atau sering disebut pendekatan behavioristik dan struktural berasumsi bahwa manusia itu pasif, sedangkan pendekatan subjektif memandang manusia aktif (fenomenologis dan interpretif).

Ini berarti, yang yang ditekankan dalam penelitian ini ialah aspek subjektif dari perilaku wanita karier terhadap keluarga. Hal ini dilakukan agar peneliti dapat memasuki dunia konseptual para subjek yang ditelitinya. Sebagaimana dikatakan Moustakas:

"The empirical phenomenological approach involves a return to experience in order to obtain comprehensives descripsions that provide the basis for a reflective structural analysis that potrays the essences of the experience. The approach "seeks to disclose and elucidate the phenomena of behavior as they manifest themselves in their perceived immediacy" (1994:13)

Penelitian berdasarkan perspektif fenomenologis dalam penelitian digunakan untuk mengetahui motif wanita karier dalam meniti karier, melihat dan menggambarkan lebih jauh kesadaran wanita karier dalam mewujudkan keluarga yang harmonis yang tergambar dari perilaku dan tindakan yang dilakukan oleh wanita karier.

\section{Prosedur Pengumpulan Data}

Aktivitas pengumpulan data yang peneliti lakukan mengacu pada aktivitas pengumpulan data dari Creswell, yaitu A Data Collection Circle (Kuswarno, 2009:130). Aktivitas yang dilakukan dengan model Creswell memperlihatkan bahwa satu sama lain saling berhubungan, diawali dengan penentuan tempat atau individu.

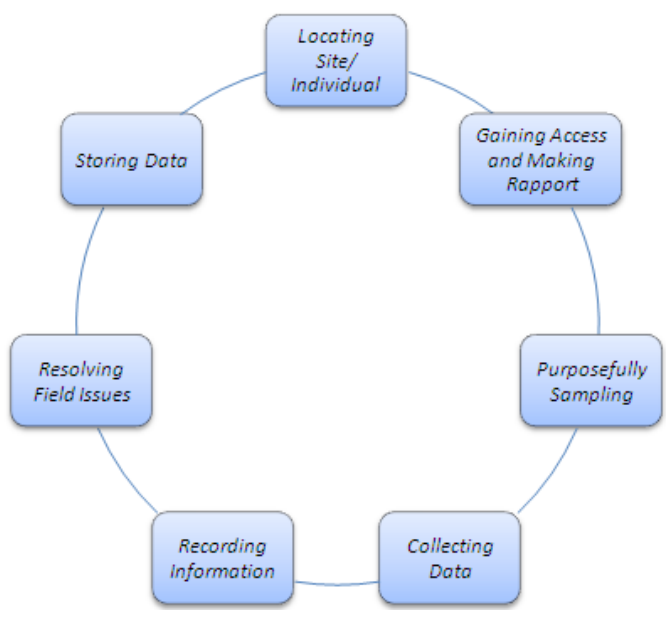

Gambar 1 A Data Collecting Circle

Sumber: Creswell dalam Kuswarno, 2009: 130 


\section{Penentuan Lokasi dan Individu}

Lokasi penelitian untuk studi fenomenologi bisa pada satu tempat atau tersebar dengan memperhatikan individu yang akan dijadikan informan baik satu orang atau lebih yang dapat memberikan penjelasan dengan baik. Penelitian ini dilakukan di Bandung (di sekitar tempat tinggal informan). Penelitian ini difokuskan pada wanita karier dengan jumlah informan sebanyak lima orang. Penentuan informan dilakukan secara purposive.

\section{Proses Pendekatan}

Pada model A Data Collecting Circle dari Creswell, proses pendekatan ini disebut sebagai Gaining Access and Making Rapport. Peneliti melakukan pendekatan dengan bertemu dan mendatangi langsung subjek atau informan. Saat bertemu peneliti mencoba berkomunikasi secara informal sampai akhirnya peneliti menyampaikan maksud dan tujuan peneliti terhadap informan tersebut.

\section{Pemilihan Informan}

Menurut Cresswell dalam Kuswarno (2009:132) kriteria informan yang baik adalah: "all individuals studied represent people who have experienced the phenomenon" (Creswell, 1998:118). Jadi, peneliti memilih informan yang benar-benar seorang wanita karier yang karena pengalamannya, dia mampu mengartikulasikan pengalaman dan pandangannya tentang sesuatu yang ditanyakan.

Peneliti memutuskan informan yang dapat memberikan informasi yang relevan dan dapat membantu menjawab pertanyaan penelitiannya. Dalam penelitian ini subjek penelitian atau informan memiliki karakteristik umum sebagai berikut : (1) Wanita berusia 25 - 35 tahun; (2) Wanita yang bersuami dan mempunyai anak; (3) Pendidikan terakhir minimal Sarjana (S1). (4) Mempunyai pekerjaan tetap di luar rumah baik sebagai pegawai negeri maupun pegawai swasta dengan peluang peningkatan dalam pekerjaannya (memiliki jenjang karier atau track record dalam kariernya); (5) Memiliki jabatan yang tinggi dalam pekerjaan. (6) Bekerja di luar rumah lebih dari delapan jam; (7) Berpenghasilan di atas upah minimum kerja di Bandung; (8) Bertempat tinggal di Bandung.

Tabel 1 Data Informan para Wanita Karier

\begin{tabular}{clccccc}
\hline No. & $\begin{array}{c}\text { Nama } \\
\text { (Samaran) }\end{array}$ & Umur & $\begin{array}{c}\text { Pendidikan } \\
\text { Terakhir }\end{array}$ & Pekerjaan & $\begin{array}{c}\text { Lama } \\
\text { Bekerja }\end{array}$ & Tempat Bekerja \\
\hline 1. & Lila & 35 tahun & S1 Akuntansi & Sekretaris Direksi & 12 tahun & Perusahaan Farmasi \\
\hline 2. & Maya & 29 tahun & S1 Manajemen & $\begin{array}{c}\text { Secretary of } \\
\text { Corporate Affair }\end{array}$ & 6 tahun & BUMN \\
\hline 3. & Yeni & 30 tahun & $\begin{array}{c}\text { S1 Komunikasi } \\
\text { (Public Relations) }\end{array}$ & $\begin{array}{c}\text { Head of Corporate } \\
\text { Communication }\end{array}$ & 7 tahun & $\begin{array}{c}\text { Perusahaan } \\
\text { Telekomunikasi }\end{array}$ \\
\hline 4. & Fita & 32 tahun & S1 Manajemen & $\begin{array}{c}\text { Marketing } \\
\text { Manager }\end{array}$ & 9 tahun & Perusahaan Swasta \\
\hline 5. & Lina & 31 tahun & $\begin{array}{c}\text { S2 Teknik } \\
\text { Lingkungan }\end{array}$ & $\begin{array}{c}\text { Dosen dan } \\
\text { Konsultan }\end{array}$ & 8 tahun & $\begin{array}{c}\text { Perguruan Tinggi } \\
\text { Swasta dan Perusahaan } \\
\text { Milik Sendiri }\end{array}$ \\
\hline
\end{tabular}

\section{Teknik Pengumpulan Data}

Pengumpulan data dilakukan dengan cara: (1) Observasi; (2) Wawancara Tak Terstruktur atau wawancara mendalam (in-depth interview); (3) Studi Dokumentasi 


\section{Prosedur Pencatatan Data}

Pencatatan wawancara mendalam dilakukan setelah wawancara selesai karena sifat wawancara yang informal. Pencatatan wawancara mendalam dalam penelitian ini dilakukan dengan menggunakan alat perekam (tape recorder).

\section{Isu-isu lapangan}

Isu-isu lapangan ditujukan untuk merekam beberapa kejadian ketika sedang melakukan pengamatan. Selain dimulai dengan mempersiapkan pedoman melakukan pengamatan, pada tahap ini diperlukan juga aktivitas pencatatan kejadian-kejadian yang berkaitan dengan isu yang menjadi pokok dalam penelitian ini.

\section{Penyimpanan Data}

Data disimpan dengan cara: (1) Senantiasa mempunyai arsip cadangan (backup copies) dalam file computer; (2) Menuliskan sebuah daftar untuk jenis-jenis informasi yang diperoleh; (3) Melindungi partisipan yang ingin ditulis anonim; (4) Mengembangkan matriks data sebagai cara untuk menggambarkan letak dan identifikasi informasi pada studi.

\section{Metode Analisis Data}

Tabel 2 Teknik Analisis dan Representasi Data

\begin{tabular}{ll}
\hline \multicolumn{1}{c}{ Analisis dan Representasi Data } & \multicolumn{1}{c}{ Penelitian Fenomenologi } \\
\hline Pengolahan data & Membuat dan mengorganisasikan data \\
\hline Membaca dan mengingat data & $\begin{array}{l}\text { Membaca teks, membuat batasan-batasan catatan, dan membuat form } \\
\text { kode-kode inisial. }\end{array}$ \\
\hline Menggambarkan data & Menggambarkan makna dari peristiwa untuk peneliti. \\
\hline Mengklasifikasikan data & Menemukan pernyataan-pernyataan bermakna, dan membuat daftarnya. \\
& $\begin{array}{l}\text { Mengelompokkan pernyataan-pernyataan yang sama ke dalam unit-unit } \\
\text { makna tertentu. }\end{array}$ \\
\hline Interpretasi data & Membangun deskripsi tekstural (apa yang terjadi). \\
& Membangun deskripsi struktural (bagaimana peristiwa itu dialami) \\
& Membangun deskripsi keseluruhan dari peristiwa (esensi peristiwa) \\
\hline Visualisasi dan presentasi data & Narasi esensi peristiwa, dilengkapi dengan tabel pernyataan dan unit- \\
& unit makna. \\
\hline
\end{tabular}

\section{Teknik Validasi Data}

Menurut Bungin dalam Ruslan (2003: 44), triangulasi adalah memeriksa kebenaran data yang diperoleh kepada pihak lain yang dipercaya. Sementara Moleong (2001: 32) menjelaskan triangulasi adalah teknik pemeriksaan keabsahan data yang memanfaatkan sesuatu yang lain di luar data itu untuk keperluan pengecekan atau sebagai pembanding terhadap data itu. Teknik triangulasi yang paling banyak digunakan ialah pemeriksaan melalui sumber.

Sebagaimana yang dikatakan Humphrey dalam Kuswarno (2009: 74), dalam metode penelitian fenomenologi, teknik validasi data dapat dilakukan dengan mengirimkan hasil penelitian kepada masing-masing informan, dan meminta mereka untuk mengoreksi atau memberikan masukan. 


\section{HASIL DAN PEMBAHASAN}

\section{Motif Berkarier}

Menurut Winkel dalam Khodijah (2006: 31) menyatakan motif adalah daya penggerak dalam diri seseorang untuk melakukan kegiatan tertentu demi mencapai suatu tujuan tertentu. Menurut Azwar dalam Khodijah (2006: 31), disebutkan bahwa motif adalah suatu keadaan, kebutuhan, atau dorongan dalam diri seseorang yang disadari atau tidak disadari yang membawa kepada terjadinya suatu perilaku. Pengertian lain datang dari Nasution dalam Sobur (2003:267) bahwa motif adalah segala daya yang mendorong seseorang untuk melakukan sesuatu. Dari beberapa pendapat di atas, maka dapat disimpulkan bahwa motif merupakan suatu dorongan dan kekuatan yang berasal dari dalam maupun luar diri seseorang baik yang disadari maupun tidak disadari untuk melakukan sesuatu.

Tabel 3 Motif Wanita karier dalam Meniti Karier

\begin{tabular}{|c|c|c|}
\hline $\begin{array}{c}\text { Nama } \\
\text { Informan }\end{array}$ & $\begin{array}{c}\text { Motif meniti Karier } \\
\text { (meaning unit) }\end{array}$ & Kesimpulan \\
\hline Lila & $\begin{array}{l}\text { Saya berpikir kalau saya tidak bekerja setelah lulus kuliah, rasanya sia-sia } \\
\text { ilmu yang saya dapatkan saat kuliah, dan saat itu saya pikir, kalo nikah saya } \\
\text { bisa bantu suami buat biaya rumah tangga kami.(wawancara } 10 \text { Juli 2011). }\end{array}$ & $\begin{array}{l}\text { Mengaplikasikan ilmu yang } \\
\text { dimiliki dan membantu } \\
\text { perekonomian rumah tangga }\end{array}$ \\
\hline Maya & $\begin{array}{l}\text {...aku bisa punya penghasilan buat membantu ekonomi keluarga... Selain itu, } \\
\text { sayang kan aku udah kuliah mahal-mahal tapi nggak dimanfaatin ilmunya. } \\
\text { Juga, bisa punya banyak temen, punya banyak pengalaman yang seru... } \\
\text { (wawancara } 26 \text { Juni 2011). }\end{array}$ & $\begin{array}{l}\text { Membantu perekonomian } \\
\text { keluarga, mengaplikasikan } \\
\text { ilmu yang dimiliki dan } \\
\text { sosialisasi }\end{array}$ \\
\hline Yeni & $\begin{array}{l}\text { Self-actualisation and socialization...aku ingin membuat jaringan yang luas, } \\
\text { kenal banyak orang, juga kalau punya penghasilan sendiri, enak, ga usah } \\
\text { minta suami if I want something that I need... (Wawancara } 12 \text { Juni 2011) }\end{array}$ & $\begin{array}{l}\text { Aktualisasi diri, sosialisasi, } \\
\text { dan memiliki penghasilan } \\
\text { sendiri }\end{array}$ \\
\hline Fita & $\begin{array}{l}\text { Saya ingin ketika saya menikah, saya hanya berpangku tangan pada suami. } \\
\text { Saya ingin menunjukkan bahwa saya juga berguna bagi banyak orang dan } \\
\text { bisa membantu suami (Wawancara } 19 \text { Juni 2011). }\end{array}$ & $\begin{array}{l}\text { Memiliki penghasilan sendiri, } \\
\text { aktualiasasi diri, dan } \\
\text { membantu perekonomian } \\
\text { rumah tangga }\end{array}$ \\
\hline Lina & $\begin{array}{l}\text { Keinginan untuk mempertajam keahlian bidang teknik lingkungan sesuai } \\
\text { perkembangan teknologi dan menjaga hubungan baik (relasi pekerjaan) di } \\
\text { kalangan akademisi dan konsultan agar jika suatu saat saya membutuhkan } \\
\text { bantuan teknis terkait pekerjaan, saya akan mendapatkan kemudahan } \\
\text { (Wawancara 5Juni 2011). }\end{array}$ & $\begin{array}{l}\text { Mengaplikasikan dan } \\
\text { mengembangkan ilmu yang } \\
\text { dimiliki dan sosialiasi }\end{array}$ \\
\hline
\end{tabular}

Dari tabel di atas terlihat bahwa ada lima macam motif yang mendorong para wanita karier dalam penelitian ini untuk meniti karier di samping statusnya sebagai ibu rumah tangga. Motif-motif tersebut diantaranya:

\section{Membantu perekonomian keluarga}

Dalam kehidupan manusia kebutuhan ekonomi merupakan kebutuhan primer yang dapat menunjang kebutuhan yang lainnya. Dengan berkarier, seorang wanita tentu saja mendapatkan imbalan yang kemudian dapat dimanfaatkan untuk menambah dan mencukupi kebutuhan sehari-hari. Dalam konteks pembicaraan keluarga yang modern, wanita tidak lagi dianggap sebagai mahluk yang semata-mata tergantung pada penghasilan suaminya, melainkan ikut membantu berperan dalam meningkatkan penghasilan keluarga untuk satu pemenuhan kebutuhan keluarga yang semakin bervariasi.

Pada masa Rasulullah sendiri, ada banyak wanita yang juga dikenal sebagai wanita karier. Siti Khadijah, istri Nabi, adalah salah satu di antaranya. Namun demikian, kita semua tahu bahwa ekonomi bukanlah satu-satunya tujuan kita hidup di dunia. Pada kenyataannya ekonomi hanyalah sarana untuk menopang sisi-sisi kehidupan yang lain. 


\section{Mengaplikasikan ilmu yang dimiliki}

Semakin berkembangnya zaman, semakin jarang membahas mengenai pentingnya menjadi ibu. Banyak anggapan bahwa daripada hanya menjadi seorang ibu, bakat dan kemampuan seorang wanita seharusnya bisa digunakan untuk hal-hal lain yang jauh lebih baik, apalagi jika wanita tersebut seorang sarjana.

\section{Sosialisasi}

Wanita tetap memilih untuk bekerja karena memiliki kebutuhan sosial-relasional yang tinggi dan tempat kerja mereka mampu mencukupi kebutuhan tersebut. Dalam diri mereka terdapat suatu kebutuhan penerimaan sosial dengan adanya identitas sosial yang diperoleh melalui komunitas kerja. Bergaul dengan rekan-rekan di kantor, menjadi agenda yang lebih menyenangkan dari pada tinggal di rumah. Faktor psikologis seseorang serta keadaan internal keluarga turut mempengaruhi seorangwanita untuk tetap mempertahankan pekerjaan.

\section{Memiliki penghasilan sendiri.}

Wanita karier adalah fase atau periode lanjutan dari wanita pekerja. Di fase ini mereka sudah mulai bisa mengambil resiko dengan meninggalkan pekerjaan mereka yang sudah mapan demi anak tercinta. sedangkan wanita pekerja lebih didefinisikan sebagai wanita yang sebelum mereka menikah memang sudah bekerja sehingga sudah dari awal merasakan kebebasan finansial.

\section{Aktualisasi diri}

Banyak pendapat yang mengatakan bahwa jika seorang wanita telah menjadi wanita karier berarti dia bisa mengaktualisasikan dirinya sehingga merasa bahwa mengurus anak dan mendidik anak bukan merupakan investasi waktu dan tenaga yang berharga. Hal ini seringkali menimbulkan rasa tak berguna bagi para ibu jika hanya tinggal di rumah dan faktor emansipasi sering menjadi kambing hitam untuk lebih eksis di luar rumah.

Abraham Maslow pada tahun 1960 mengembangkan teori hirarki kebutuhan, yang salah satunya mengungkapkan bahwa manusia mempunyai kebutuhan akan aktualisasi diri, dan menemukan makna hidupnya melalui aktivitas yang dijalaninya. Kebutuhan akan aktualisasi diri melalui profesi atau pun karier merupakan salah satu pilihan yang banyak diambil oleh para wanita di jaman sekarang ini, terlebih dengan semakin terbukanya kesempatan yang sama pada wanita untuk meraih jenjang karier yang tinggi.

\section{Makna Karier}

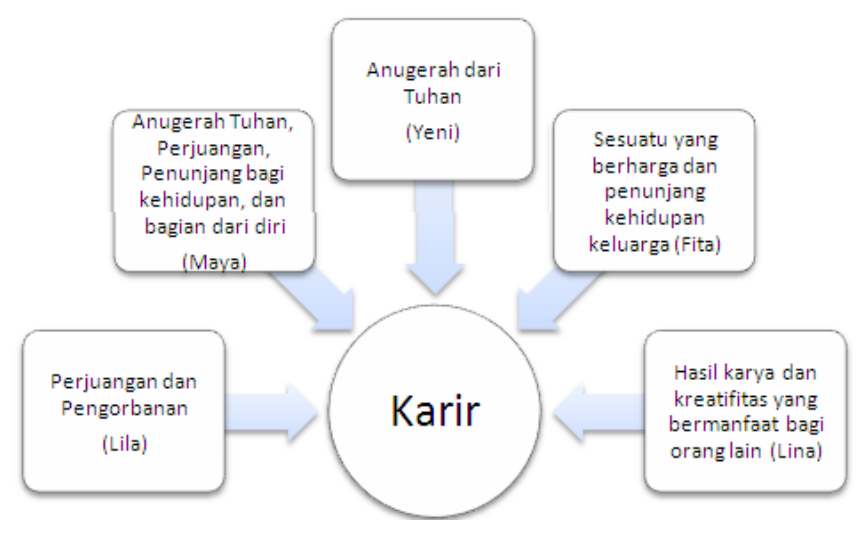

Gambar 2 Makna Karier bagi wanita karier

Sumber: Pengumpulan Data, Juni 2011-Agustus 2011 
Dari makna-makna di atas terdapat makna yang sama yaitu karier adalah anugerah Tuhan, perjuangan, dan penunjang kehidupan. Bila dibuat menjadi satu kesatuan maka makna karier bagi wanita karier dalam penelitian ini adalah suatu anugerah dari Tuhan yang diraih dengan penuh perjuangan dan pengorbanan dan juga sesuatu yang berharga yang menjadi penunjang kehidupan serta menghasilkan karya dan kreatifitas yang bermanfaat bagi orang lain.

\section{Makna Keluarga}

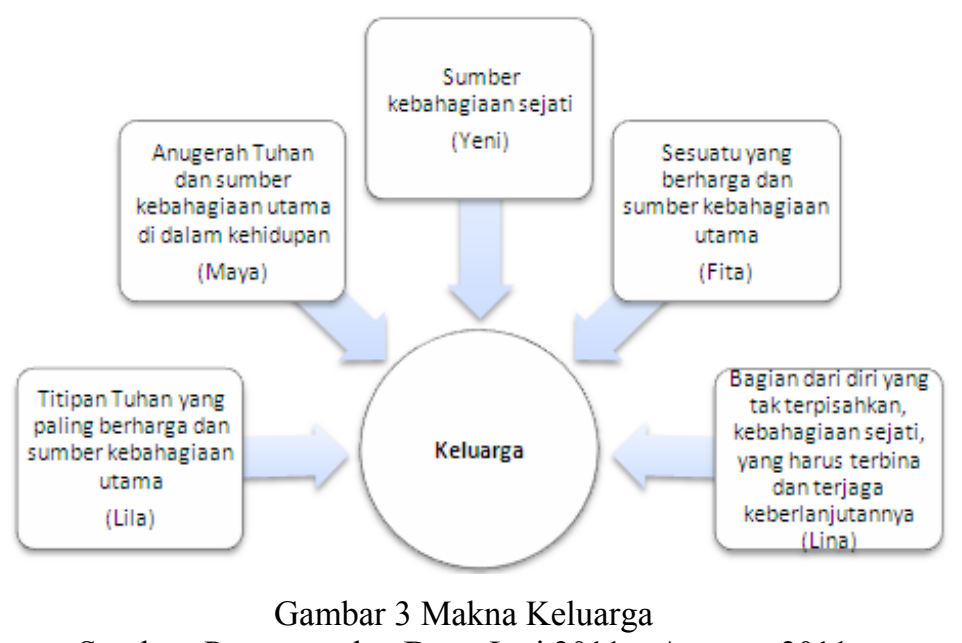

Sumber: Pengumpulan Data, Juni 2011 - Agustus 2011

Makna-makna di atas memiliki beberapa kesamaan seperti makna keluarga bagi para wanita karier adalah sumber kebahagiaan utama. Dapat disimpulkan lagi bahwa makna keluarga bagi wanita karier dalam penelitian ini adalah sumber kebahagiaan utama dalam kehidupan yang merupakan Anugerah dan titipan dari Tuhan dan juga sesuatu yang berharga yang harus terbina dan terjaga.

\section{Makna Komunikasi Keluarga bagi Wanita Karier}

Komunikasi dalam keluarga jika dilihat dari segi fungsinya tidak jauh berbeda dengan fungsi komunikasi pada umumnya. Paling tidak ada dua fungsi komunikasi dalam keluarga, yaitu fungsi komunikasi sosial dan fungsi komunikasi kultural. Fungsi komunikasi sebagai komunikasi sosial setidaknya mengisyaratkan bahwa komunikasi itu penting untuk membangun konsep diri, aktualisasi diri, kelangsungan hidup, memperoleh kebahagiaan, menghindarkan diri dari tekanan dan ketegangan. Selain itu, melalui komunikasi seseorang dapat bekerja sama dengan anggota masyarakat - terlebih dalam keluarga - untuk mencapai tujuan bersama (Mulyana dalam Djamarah, 2004: 37). Sedang fungsi komunikasi kultural, diasumsikan dari pendapat para sosiolog bahwa komunikasi dan budaya mempunyai hubungan timbal balik. Budaya menjadi bagian dari komunikasi. Peranan komunikasi disini adalah turut menentukan, memelihara, mengembangkan atau mewariskan budaya. Jika demikian, benar kata Edward T. Hall bahwa "budaya adalah komunikasi" dan "komunikasi adalah budaya". (Djamarah, 2004: 37).

\section{Makna Komunikasi Istri terhadap Suami}

Upaya wanita karier di dalam penelitian ini dalam membina komunikasi interpersonal (lihat tabel 4) yang baik dengan suami di lakukan melalui beberapa hal, seperti: (1) Selalu melibatkan pasangan dalam menyelesaikan persoalan rumah tangga khususnya masalah anak. (2) Memberi bantuan dan dukungan melalui kerja sama dalam menyelesaikan pekerjaan rumah tangga yang jika pekerjaan itu hanya dibebankan sepenuhnya kepada istri yang juga bekerja di luar rumah 
dikhawatirkan dapat mengganggu keharmonisan dalam rumah tangga. (3) Selalu menyempatkan waktu untuk dapat berdua dengan pasangan seperti mengefektifkan dan memanfaatkan waktu-waktu seperti menjelang tidur, ketika selesai shalat berjamaah atau ketika pergi berdua ke suatu tempat. (4) Ketika tidak dapat berkomunikasi secara tetap muka maka solusi yang digunakan untuk tetap dapat menjalin komunikasi yang baik dengan pasangan adalah melalui media komunikasi seperti mobile phone atau handphone, dengan cara baik menelepon secara langsung atau melalui fasilitas pengiriman pesan teks (Short Message Service) atau chatting melalui fasilitas Blackberry Messenger yang sedang trend saat ini.

Tabel 4 Cara Komunikasi Wanita Karier dengan Suaminya

\begin{tabular}{|c|c|c|c|}
\hline \multirow{2}{*}{$\begin{array}{l}\text { Nama } \\
\text { Informan }\end{array}$} & \multicolumn{2}{|c|}{$\begin{array}{l}\text { Cara komunikasi dengan suami } \\
\text { (meaning unit) }\end{array}$} & \multirow{2}{*}{$\begin{array}{c}\text { Makna } \\
\text { (meaning unit) }\end{array}$} \\
\hline & Verbal & Non Verbal & \\
\hline Lila & $\begin{array}{l}\text { Kalo lagi di kantor saya suka } \\
\text { telepon mereka lewat 'hp'. } \\
\text { (Wawancara dengan Lila, } 10 \\
\text { Juli 2011) }\end{array}$ & $\begin{array}{l}\text { Kejutan-kejutan kecil juga kadang saya } \\
\text { berikan pada suami seperti } \\
\text { memberikannya hadiah kado untuk ulang } \\
\text { tahunnya. Walaupun bukan yang mahal } \\
\text { tapi saya percaya hal seperti itu bisa } \\
\text { menambah kedekatan kami. (Wawancara } \\
\text { dengan Lila, 10 Juli 2011) }\end{array}$ & $\begin{array}{l}\text { Ya...artinya saya sayang dan } \\
\text { peduli sama mereka...saya } \\
\text { perhatian sama mereka, } \\
\text { walaupun saya jarang ketemu } \\
\text { sama mereka. (Wawancara } \\
\text { dengan Lila, } 10 \text { Juli 2011) }\end{array}$ \\
\hline Maya & $\begin{array}{l}\text { Kalo sama suami otomatis } \\
\text { lewat handphone juga paling } \\
\text { BBMan. (Wawancara } \\
\text { dengan Maya, 26 Juni 2011). }\end{array}$ & $\begin{array}{l}\text { aku sama suami kalau lagi ada waktu, kita } \\
\text { berdua saja pergi jalan, nonton.. ( } \\
\text { Wawancara dengan Maya, } 26 \text { Juni 2011). }\end{array}$ & Rasa sayang dan kepedulian \\
\hline Yeni & $\begin{array}{l}\text { Kalau sama suami ya by } \\
\text { mobile phone...call or } \\
\text { chatting.. (Wawancara } \\
\text { dengan Yeni, } 12 \text { Juni 2011). }\end{array}$ & $\begin{array}{l}\text { Hmm...kalau ama suami...kadang aku } \\
\text { minta makan siang bareng pas istirahat } \\
\text { kantor, aku suka ngasih dia kejutan- } \\
\text { kejutan kecil, misalnya, masakin makanan } \\
\text { kesukaannya, kalau lagi sempet kita non } \\
\text { ton berdua aja, kaya gitu-gitu...hehe. } \\
\text { (Wawancara dengan Yeni, 12 Juni 2011). }\end{array}$ & $\begin{array}{l}\text { Rasa sayang, kepedulian, } \\
\text { menjaga cinta dan kedekatan } \\
\text { dengan suami }\end{array}$ \\
\hline Fita & $\begin{array}{l}\text { Ya pasti lewat telepon } \\
\text { genggam...kumaha } \\
\text { deui...(Wawancara dengan } \\
\text { Fita, } 19 \text { Juni 2011) }\end{array}$ & $\begin{array}{l}\text { Hmm...kalau sama suami...saya suka } \\
\text { masakin makanan kesukaan beliau, mijitin } \\
\text { beliau kalau lagi lelah, ya kejutan-kejutan } \\
\text { kecil di saat-saat yang tepat.(Wawancara } \\
\text { dengan Fita, 19 Juni 2011) }\end{array}$ & $\begin{array}{l}\text { Sangat penting biar cinta tetap } \\
\text { terpelihara sehingga perkawinan } \\
\text { tetap terjaga. (Wawancara } \\
\text { dengan Lina, } 5 \text { Juni 2011.). }\end{array}$ \\
\hline Lina & $\begin{array}{l}\text { Jika di luar rumah untuk } \\
\text { keperluan kerja, saya } \\
\text { berinteraksi lewat telepon } \\
\text { dengan suami. (Wawancara } \\
\text { dengan Lina, } 5 \text { Juni 2011.) }\end{array}$ & $\begin{array}{l}\text { Kalau sehari-hari A Feri pulang kantor kan } \\
\text { sore bahkan malam jika ada tugas } \\
\text { tambahan, saya biasanya selalu } \\
\text { menyediakan air hangat buat A Feri mandi } \\
\text { karena itu sudah jadi kebiasaannya, terus } \\
\text { nyiapin makanan bersama pembantu tapi } \\
\text { kadang-kadang saya juga bikin surprise } \\
\text { seperti nyuruh dia pulang kantor lebih } \\
\text { awal. kejutannya ya masakin makanan } \\
\text { kesukaannya tapi yang lebih istimewa } \\
\text { dibanding hari-hari biasanya tanpa dia } \\
\text { minta sebelumnya. (Wawancara dengan } \\
\text { Lina, } 5 \text { Juni } 2011 \text {. }\end{array}$ & $\begin{array}{l}\text { Saya memaknai interaksi } \\
\text { dengan suami sebagai bentuk } \\
\text { kasih sayang dan suatu hal yang } \\
\text { harus dilakukan sesuai porsinya } \\
\text { misalnya komunikasi via telpon } \\
\text { atau obrolan langsung di rumah } \\
\text { atau di luar rumah, sehingga } \\
\text { menimbulkan kenyamanan, } \\
\text { tidak kaku, dan meningkatkan } \\
\text { kepercayaan dalam hubungan } \\
\text { rumah tangga. (Wawancara } \\
\text { dengan Lina, } 5 \text { Juni 2011.) }\end{array}$ \\
\hline
\end{tabular}

Makna komunikasi istri terhadap suami yang diungkapkan para wanita karier dalam penelitian ini (lihat gambar 4) hampir sama, yaitu rasa sayang, kepedulian, rasa cinta, menjaga kedekatan dengan suami. Maka, dapat disimpulkan bahwa makna komunikasi para wanita karier dengan suaminya adalah sebagai bentuk nyata dari rasa sayang, kepedulian, dan rasa cinta serta sebagai cara untuk menjaga kedekatan atau keakraban dengan suami dan keutuhan perkawinan. 


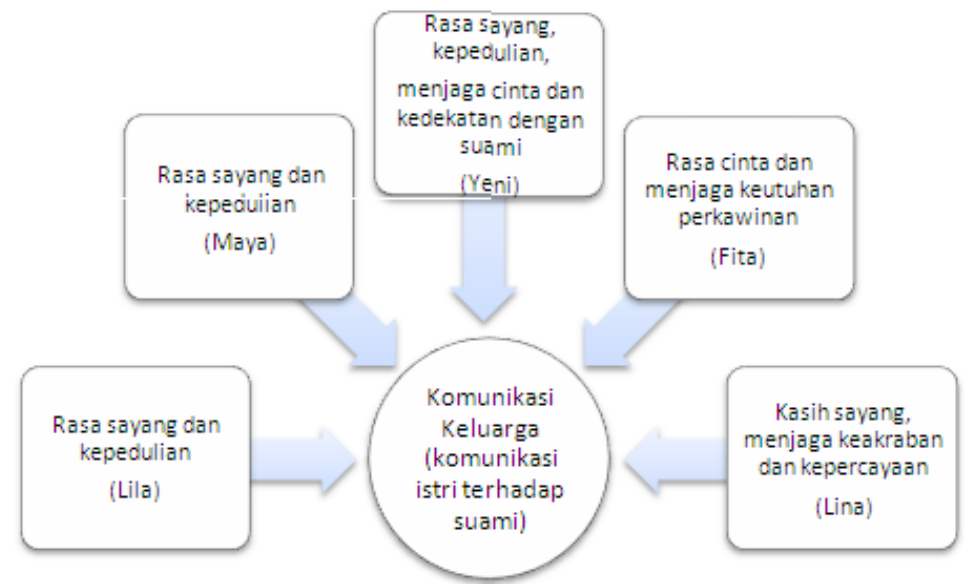

Gambar 4 Makna Komunikasi Keluarga (komunikasi istri terhadap suami) Sumber: Pengumpulan Data, Juni 2011- Agustus 2011

\section{Makna Komunikasi Ibu terhadap Anak}

Para Ibu yang bekerja dalam penelitian ini (lihat tabel 5) biasanya menyediakan waktu untuk bersama anaknya. Diantaranya melalui: (1) Menyediakan waktu berdua dengan anak untuk berbincang-bincang mengenai pelajaran sekolahnya, teman-temannya, bermain dengannya di dalam rumah atau sesekali makan di luar bersamanya. (2) Terlibat bersama dalam satu kegiatan, membacakan sebuah buku cerita kesukaan anak, menonton acara TV bersifat edukatif dan disukai anak, mengajak anak untuk menemani berbelanja, atau kegiatan yang bernilai ibadah seperti sholat berjamaah. (3) Memberikan perhatian pada kesempatan-kesempatan khusus, seperti mengobrol santai dengan anak saat ia akan berangkat tidur, merayakan ulang tahun anak sesuai dengan pilihannya sendiri asalkan masih sesuai kemampuan, atau mengisi hari libur sekolah dengan rekreasi ke suatu tempat. (5) Memberikan perhatian melalui ucapan-ucapan bahwa ibu sangat mencintainya dan menyayanginya, bentuk perhatian tersebut diiringi dengan ungkapan bahasa nonverbal seperti: memeluknya sambil berkata: "Anak mama yang cantik" atau bentuk pujian yang lain seperti "kamu pintar sekali nak" sambil memegang pundaknya dan tersenyum padanya. (6) Memanfaatkan saluran/ channel dalam berkomunikasi dengan anak seperti melalui pemanfaatan mobile phone atau telepon rumah untuk mempermudah berkomunikasi dan mengetahui hal-hal yang dilakukan anak ketika ibu sedang bekerja karena tidak dapat bertatap muka langsung dengan anak.

Tabel 5 Cara Komunikasi Ibu terhadap Anak

\begin{tabular}{|c|c|c|c|}
\hline \multirow{2}{*}{$\begin{array}{l}\text { Nama } \\
\text { Informan }\end{array}$} & \multicolumn{2}{|c|}{$\begin{array}{c}\text { Cara Komunikasi Ibu terhadap Anak } \\
\text { (Meaning Unit) }\end{array}$} & \multirow{2}{*}{$\begin{array}{c}\text { Makna } \\
\text { (Meaning Unit) }\end{array}$} \\
\hline & Verbal & Non Verbal & \\
\hline Lila & $\begin{array}{l}\text { Kalo lagi di kantor saya suka telepon } \\
\text { mereka lewat 'hp'. } \\
\text { Sama anak-anak ya saya tetap } \\
\text { berusaha jadi Ibu yang baik, tanya } \\
\text { gimana sekolahnya, tapi seringnya } \\
\text { mereka yang cerita sendiri sama } \\
\text { saya, saya biasanya jadi pendengar } \\
\text { yang baik. (Wawancara dengan Lila, } 10 \\
\text { Juli 2011) }\end{array}$ & $\begin{array}{l}\text { Kalau hari Sabtu sama Minggu itu kan } \\
\text { papanya anak-anak sama saya libur kerja, } \\
\text { jadi ya waktu-waktu itulah biasa saya } \\
\text { gunakan buat ajak anak-anak jalan, } \\
\text { kadang membeli keperluan rumah } \\
\text { bersama di Carrefour, setelah itu } \\
\text { mengajak anak-anak makan dan kadang } \\
\text { membelikan baju buat mereka. } \\
\text { (Wawancara dengan Lila, 10 Juli 2011) }\end{array}$ & $\begin{array}{l}\text { Ya...artinya saya sayang dan } \\
\text { peduli sama mereka...saya } \\
\text { perhatian sama mereka, } \\
\text { walaupun saya jarang } \\
\text { ketemu sama mereka. } \\
\text { (Wawancara dengan Lila, } 10 \text { Juli } \\
\text { 2011) }\end{array}$ \\
\hline Maya & $\begin{array}{l}\text { Sepulang kerja aku paling sering } \\
\text { ngobrol dengan Caca, dengerin } \\
\text { hafalan doa-doanya, } \\
\text { Alhamdulillah...dia mulai lancar atau } \\
\text { sekedar bacain cerita kalo mau tidur. }\end{array}$ & $\begin{array}{l}\text { Apa ya...banyak sih, misalnya ya kalo } \\
\text { hari libur kita pergi bersama, } \\
\text { bertiga...ngajak Caca main. (Wawancara } \\
\text { dengan Maya, } 26 \text { Juni 2011) }\end{array}$ & $\begin{array}{l}\text { Rasa sayang, kepedulian, } \\
\text { mengajar dan mendidik. }\end{array}$ \\
\hline
\end{tabular}




\begin{tabular}{|c|c|c|c|}
\hline & $\begin{array}{l}\text { Kadang kalau aku liat dia lagi jenuh } \\
\text { biasanya aku ngajakin dia ngomong- } \\
\text { ngomong sama bonekanya atau juga } \\
\text { nyanyi sama-sama. (Wawancara } \\
\text { dengan Maya, 26 Juni 2011) }\end{array}$ & & \\
\hline Yeni & $\begin{array}{l}\text {...aku memantau anak melalui } \\
\text { telepon rumah saja dengan } \\
\text { menanyakan bagaimana keadaannya } \\
\text { selama aku bekerja apa sudah } \\
\text { makan, mandi,melalui telepon. } \\
\text { (Wawancara dengan Yeni, } 12 \text { Juni } \\
\text { 2011) }\end{array}$ & $\begin{array}{l}\text { Aku tahu gak banyak waktu untuk bisa } \\
\text { berkumpul sama-sama, jadi kadang } \\
\text { pulang kerja aku selalu membawa kejutan } \\
\text { untuk anak-anak atau kalau tidak begitu } \\
\text { biasanya ketika jam istirahat di kantor } \\
\text { aku menelpon mereka menanyakan apa } \\
\text { ada sesuatu yang lagi mereka pingin } \\
\text { kemudian aku membelikannya untuk } \\
\text { mereka. Ketika sholat maghrib bersama } \\
\text { suami dan anak-anak adalah suatu hal } \\
\text { terindah dari sepanjang hari, karena di } \\
\text { situlah tercipta kedekatanku dengan } \\
\text { mereka dan dengan Tuhan kami dalam } \\
\text { waktu yang bersamaan. (Wawancara } \\
\text { dengan Yeni, 12 Juni 2011). }\end{array}$ & $\begin{array}{l}\text { Rasa sayang, kepedulian dan } \\
\text { menjaga keakraban }\end{array}$ \\
\hline Fita & $\begin{array}{l}\text { Ya pasti lewat telepon } \\
\text { genggam...kumaha deui. } \\
\text {... membacakan cerita, menemani } \\
\text { membuat PR...(Wawancara dengan } \\
\text { Fita, 12 Juni 2011) }\end{array}$ & $\begin{array}{l}\text { Kalau sama anak-anak misalnya kayak } \\
\text { memandikan, menyuapi, mengantar dan } \\
\text { menjemput sekolah... (Wawancara } \\
\text { dengan Fita, } 12 \text { Juni 2011) }\end{array}$ & $\begin{array}{l}\text { Sangat penting karena anak } \\
\text { butuh sekali interaksi, } \\
\text { sebagai rasa sayang dan } \\
\text { perhatian saya sama mereka. } \\
\text { (Wawancara dengan Fita, } 12 \\
\text { Juni 2011) }\end{array}$ \\
\hline Lina & $\begin{array}{l}\text { Saya mengupayakan berinteraksi } \\
\text { dengan anak sesering mungkin } \\
\text { karena dengan kedekatan dan } \\
\text { perhatian, anak selalu } \\
\text { memperlihatkan keceriannya, } \\
\text { dengan begitu saya juga dapat } \\
\text { mencermati } \\
\text { perkembangannya,bermain } \\
\text { bersamanya, bercerita... (Wawancara } \\
\text { dengan Lina, } 5 \text { Juni 2011) }\end{array}$ & $\begin{array}{l}\text {...misalnya nonton acara televisi untuk } \\
\text { anak, bermain bersama, mendampinginya } \\
\text { jalan-jalan. Pada beberapa kesempatan, } \\
\text { saya terbiasa membawa anak ke tempat } \\
\text { kerja (di luar rumah) sehingga kedekatan } \\
\text { dan keterikatan dengan anak terasa. } \\
\text { (Wawancara dengan Lina, } 5 \text { Juni } 2011 \text { ) }\end{array}$ & $\begin{array}{l}\text { Interaksi dengan anak saya } \\
\text { maknai sebagai waktu-waktu } \\
\text { untuk transfer kasih sayang, } \\
\text { saling perhatian dan berbagi, } \\
\text { melatih kemampuan motorik } \\
\text { anak, memahami psikologis } \\
\text { anak. Hal ini merupakan } \\
\text { pembelajaran yang sangat } \\
\text { berarti buat saya untuk } \\
\text { mampu membentuk pribadi } \\
\text { anak yang sholeh. } \\
\text { (Wawancara dengan Lina, } 5 \\
\text { Juni 2011) }\end{array}$ \\
\hline
\end{tabular}

Makna komunikasi ibu terhadap anak bagi wanita karier dalam penelitian ini (lihat gambar 5) adalah sebagai bentuk nyata rasa sayang dan kepedulian dan sebagai cara untuk mengajar dan mendidik sang anak serta sebagai cara untuk menjaga keakraban dengan anak.

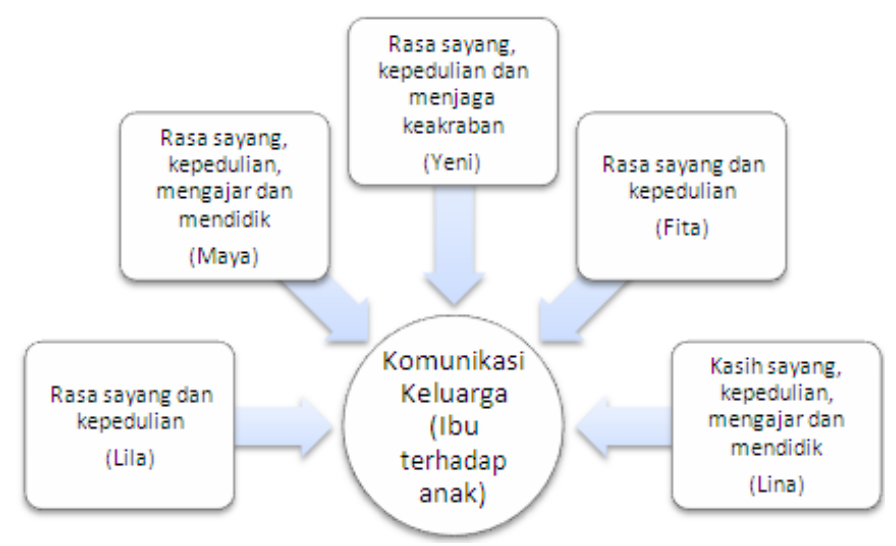

Gambar 5 Makna Komunikasi Keluarga (ibu terhadap anak) Sumber: Pengumpulan Data, Juni 2011 - Agustus 2011 
Komunikasi sebagai wahana untuk membuat anak memiliki nilai-nilai sosial diwujudkan dalam dua cara. Pertama, berkomunikasi dengan anak melalui perilaku dan atau contoh-contoh yang ditampilkan orang tua. Kedua, berkomunikasi dengan anak melalui sesuatu yang bernuansa nonverbal, seperti sentuhan, gerakan, dan ekspresi perasaan.

Pemahaman mengenai hubungan merupakan suatu aspek penting dari studi komunikasi antarpribadi, karena hubungan berkembang dan berakhir melalui komunikasi. Sebuah keluarga yang ideal adalah sebuah keluarga yang lengkap posisi dan peranannya. Ada suami dan istri yang juga berperan sebagai bapak dan ibu bagi anak-anak mereka.

Hubungan antar anggota keluarga terbentuk melalui sebuah komunikasi yang tepat dan sesuai yang digunakan dalam keluarga dan masing-masing keluarga menerapkan pola komunikasi yang berbeda-beda dengan tergantung pada kebutuhan dan situasi yang melatarinya dan terkategori dalam pola kesamaan dimana masing-masing pihak berkedudukan sama, saling percaya dan terbuka terhadap ide-ide, pendapat serta kepercayaan pada orang lain. Dengan kondisi semacam ini, maka komunikasi yang terjadi dalam keluarga dapat seimbang dimana masing-masing pihak saling menempatkan diri sesuai peranannya.

Pada intinya setiap keluarga membutuhkan komunikasi yang tepat dan ideal pada situasi yang berbeda. Pemahaman akan media dan sarana komunikasi yang tepat akan memudahkan tercapainya tujuan komunikasi dalam keluarga itu sendiri. Masing-masing pihak akan dapat saling memahami hak dan tanggung jawab bersama dan pada akhirnya akan mampu menuntaskan dan menyelesaikan semua persoalan yang ada dalam keluarga tersebut.

Ada tiga konsep utama dalam fenomenologi, yaitu: pengalaman, makna, dan sadar yang menurut Alfred Schutz bahwa manusia sebagai makhluk sosial yang menyadari kehidupan sehari-hari adalah sebuah kesadaran sosial. Bagi fenomenologi, manusia adalah agen yang kreatif (creative agent) dalam mengontruksi dunia sosial yang berasal dari kesadaran. Wanita karier sebagai individu merupakan creative agent dalam mengonstruksi social words, sehingga wanita karier mereka memiliki kesadaran bahwa mereka adalah aktor yang mengonstruksi realitas. Hal ini terlihat dalam kesadaran wanita karier ketika berhadapan dengan realita dan inilah yang dikatakan sebagai noumena-nya.

\section{SIMPULAN}

Terdapat lima macam motif yang disadari yang berasal dari dalam diri para wanita karier yang menyebabkan mereka berjuang meniti kariernya yaitu membantu perekonomian rumah tangga, mengaplikasikan ilmu, sosialisasi, memiliki penghasilan sendiri, dan aktualisasi diri. Motif-motif yang dimiliki para wanita karier dalam penelitian ini tergolong ke dalam motif untuk (in order motives) karena ke lima macam motif tersebut berorientasi pada masa depan dan menggambarkan maksud, rencana, harapan, minat yang diinginkan para wanita karier ketika meniti kariernya. Para wanita karier dalam penelitian ini, tidak mengungkapkan alasan di masa lalunya yang menyebabkan mereka ingin meniti karier, sehingga tidak ada motif karena (because motives) yang dimiliki para wanita karier tersebut.

Makna karier bagi wanita karier dalam penelitian ini adalah suatu anugerah dari Tuhan yang diraih dengan penuh perjuangan dan pengorbanan dan juga sesuatu yang berharga yang menjadi penunjang kehidupan serta menghasilkan karya dan kreatifitas yang bermanfaat bagi orang lain. makna keluarga bagi wanita karier dalam penelitian ini adalah sumber kebahagiaan utama dalam kehidupan yang merupakan Anugerah dan titipan dari Tuhan dan juga sesuatu yang berharga yang 
harus terbina dan terjaga. Mereka semua menyatakan bahwa keluarga lebih penting daripada karier, namun mereka tetap menginginkan keduanya saling mendukung.

Para wanita karier ini masih tetap bisa berkomunikasi dengan keluarga dengan cara memanfaatkan waktu yang ada seperti ketika sarapan pagi atau makan bersama, sesudah sholat shubuh atau maghrib berjamaah, sepulang kerja, sambil mengantar anak ke sekolah ataupun berkegiatan bersama misalnya ketika bermain bersama anak. Hari libur kerja seperti Sabtu dan Minggu, menjadi waktu khusus yang disediakan oleh wanita karier ini bagi kebersamaan bersama keluarganya yaitu suami dan anaknya. Berdasarkan pengamatan dan wawancara yang telah dilakukan, penggunaan media/ sarana komunikasi seperti mobile phone cukup membantu untuk berkomunikasi dengan suami maupun anaknya selain komunikasi tatap muka yang ada. makna komunikasi para wanita karier dengan suaminya adalah sebagai bentuk nyata dari rasa sayang, kepedulian, dan rasa cinta serta sebagai cara untuk menjaga kedekatan atau keakraban dengan suami dan keutuhan perkawinan. Makna komunikasi ibu terhadap anak bagi wanita karier dalam penelitian ini adalah sebagai bentuk nyata rasa sayang dan kepedulian dan sebagai cara untuk mengajar dan mendidik sang anak serta sebagai cara untuk menjaga keakraban dengan anak.

Penelitian ini diharapkan dapat memberikan kontribusi nyata kepada para wanita karier, sebagai masukan sekaligus evaluasi dalam menjalankan proses komunikasi di keluarga sehingga semakin terciptanya komunikasi yang lebih terbuka dan efektif dalam keluarga dapat terwujud, yaitu melalui membina komunikasi yang baik dengan suami maupun anak.

Hasil penelitian ini diharapkan dapat memberikan sumbangan ilmiah dalam bidang studi komunikasi dan sebagai bahan pertimbangan untuk bacaan atau referensi bagi semua pihak. Khususnya bagi program studi Ilmu Komunikasi Fakultas Ilmu Komunikasi merupakan sumbangan teoritis dalam bidang komunikasi keluarga.

Kehadiran keluarga sebagai komunitas masyarakat terkecil memiliki arti penting dan strategis dalam pembangunan komunitas masyarakat yang lebih luas. Oleh karena itu, kehidupan keluarga yang harmonis perlu dibangun di atas dasar sistem interaksi yang kondusif. Berdasarkan hasil penelitian yang telah peneliti lakukan tentunya masih terdapat banyak kekurangan sehingga diharapkan akan adanya penelitian lebih mendalam mengenai masalah yang berkaitan dengan tema yang peneliti kaji saat ini.

\section{DAFTAR PUSTAKA}

Depdikbud. (1988). Kamus Besar Bahasa Indonesia. Jakarta

Istiyanto, S.B. (2004). Pentingnya Komunikasi Keluarga: Menelaah Posisi Ibu antara Menjadi Wanita Karier atau Penciptaan Keluarga Berkualitas. Jurnal Kom Gender. 21 (1):3

Khodijah, N. (2006). Psikologi Belajar Palembang: IAIN Raden Fatah Press.

Komaruddin. (1987). Kamus Riset. Bandung: Angkasa.

Kuswarno, Engkus. (2009). Metode Penelitian Komunikasi Fenomenologi: Konsep, Pedoman, dan Contoh Penelitian. Bandung: Widya Padjadjaran.

Maharani, D. (2008). Kehidupan Sosial Wanita Sibuk. Femina, 12. 
Moleong, L. (2001). Metode Penelitian Kualitatif. Bandung: Rosda Karya.

Moustakas, C. (1994). Phenomenological Research Methods. California: Sage Publications.

Mulyana, D. (2004). Ilmu Komunikasi Suatu Pengantar. Bandung: Remaja Rosdakarya. (2003). Metodologi Penelitian Kualitatif. Bandung: Rosda Karya.

Mulyana, D., Solatun. (2007). Metode Penelitian Komunikasi. Bandung: Rosda Karya.

Sobur, Alex. (2003). Semiotika Komunikasi. Bandung: Remaja Rosdakarya.

Wahyuni, S. (2008). Jurnal Wanita Karier dan Keluarga, 3 